\title{
Assessment of the Migration of Atlantic Cod (Gadus morhua L.) between the Stocks off West and East Greenland in 1984-86 by Means of Otolith Typing*
}

\author{
Hans-Joachim Rätz \\ Institute for Sea Fisheries \\ 2000 Hamburg 50, Federal Republic of Germany
}

\begin{abstract}
A method to identify individual cod (Gadus morhua) originating from either of the nursery areas off West or East Greenland is described. The method is based on a visual classification of individual annuli of the cod otoliths (sagitta) into three different types based on the formation of opaque and hyaline zones. The different hydrographic conditions off East and West Greenland probably affected the growth of the cod and were thus manifested as natural tags, in the form of different annuli of the otoliths.

The calculation of emigration and immigration rates using the otoliths as natural tags confirmed the cod migration derived from tagging experiments, i.e. a one-way migration from West to East Greenland. In 1984-86, a very strong and rapid emigration of maturing cod from West to East Greenland occurred. The coefficients of emigration of the cod stock off West Greenland increased with age, pointing to a homing phenomenon as the migration factor.
\end{abstract}

Key words: Cod, Greenland, migration assessment, natural tags, otoliths

\section{Introduction}

It has been recognized from extensive tagging experiments since 1931 (Schmidt, 1931), that some mature cod (Gadus morhua) migrate from West Greenland to East Greenland and further, to spawning grounds on the Icelandic continental shelf. This may also sometimes be the case for immature cod originating from the East Greenland area in close vicinity to Iceland (Fig. 1). A westerly migration of mature cod in the opposite direction rarely occurs (Hansen, 1949).

The Working Groups of the International Council for the Exploration of the Sea (ICES) and the Northwest Atlantic Fisheries Organization (NAFO) on cod stocks off Greenland consider these stocks as a single complex (Anon., 1973, 1990 and MS 1990), particularly since a larval drift from Iceland to East and West Greenland through currents seems evident (Magnússon et al., 1989).

The present study concentrated on the use of otoliths (sagitta) as a natural tag. Identification and separation of fish stocks by means of the calcified structures of individuals have frequently been applied in fisheries biology (Ihssen et al., 1981).

\section{Materials and Methods}

\section{Stock assessment}

Abundance data were derived from annual autumn groundfish surveys covering the shelf and continental slope off West and East Greenland, outside of the 3-mile boundary down to the $600 \mathrm{~m}$ isobath. The standard gear used was the $140 \mathrm{ft}$ bottom trawl with a $22 \mathrm{~m}$ horizontal opening rigged with heavy ground gear and equipped with a small mesh liner inside the cod end. The towing time was usually 30 min. and 4.5 knots. In cases of net damage or hangups before $15 \mathrm{~min}$. of towing time were completed, the haul was rejected from the evaluation. The surveys had cod as the primary target species. Autumn was chosen for the surveys, because of favourable weather and ice conditions, and by choosing autumn the cod spawning concentrations were avoided. The survey strategy was to allocate the sampling effort (number of hauls) proportionally to the abundance of cod and to the area of the strata. The annual sampling effort varied between 145, 219 and 218 hauls for 1984, 1985 and 1986, respectively. Hauls were randomly distributed within the strata, but extremely rough trawling grounds were avoided.

\footnotetext{
* This paper was intended for publication in a single issue of the J. Northw. Atl. Fish. Sci. containing a collection of papers on Greenland cod stocks (see NAFO Sci. Coun. Rep., 1991, p. 120 and 1992 p. 166). Since the publication of that issue is delayed, this paper is published here. The single issue is presently proposed for 1995.
} 


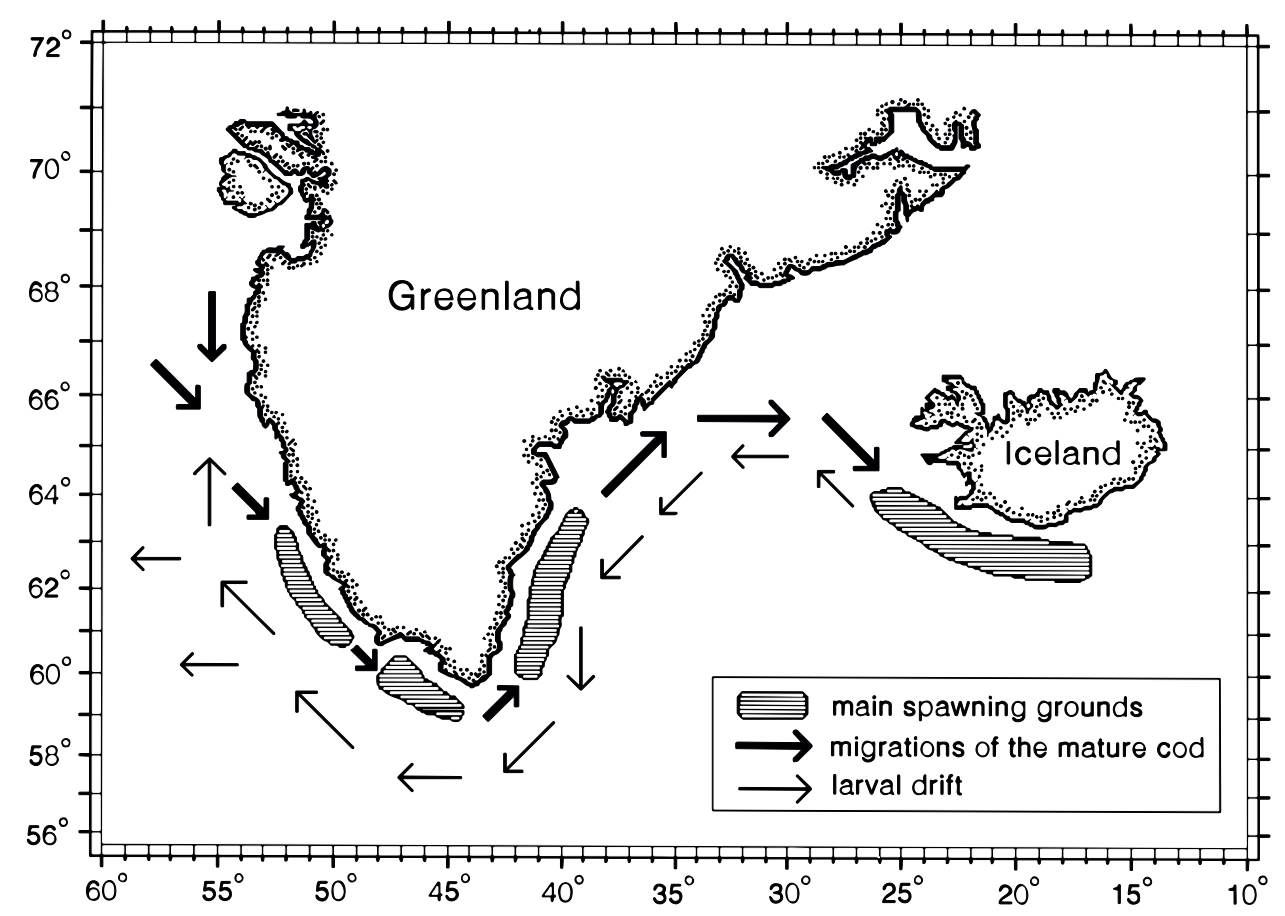

Fig. 1. Cod stock complex off West Greenland, East Greenland and Iceland (from Anon., MS 1990).

Stock assessments were carried out by the "swept area method" combined with a stratified-random sampling system (Cochran, 1977; Saville, 1977). The abundance estimates obtained were merely indices (relative abundance), as the coefficient of catchability was arbitrarily set at 1.0. Estimates of the year-class strength and of the migration rates were based only on otolith material and length-frequencies obtained during the surveys. Commercial data, although available, were not included in the assessment.

\section{Assessment of emigration and immigration}

Ricker (1975) regarded the emigration of individuals out of a stock unit as a term added to the coefficient of the total mortality rate $Z$. In accordance with the natural and fishing mortality, he thus defined an instantaneous rate of the loss of individuals due to emigration. This approach was adopted in this study in the calculation model of emigration:

$$
Z_{N}=M_{N}+F_{N}+E_{N}
$$

with

$$
\begin{aligned}
& Z_{N}=\text { total mortality of individuals grown up } \\
& \text { in a stock unit, } \\
& M_{N}=\text { natural mortality of individuals grown up }
\end{aligned}
$$

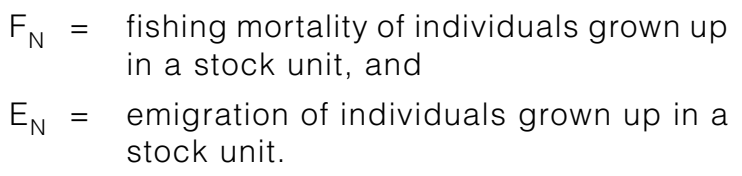

While the emigrants belong to the stock analyzed, an immigration occurs independent of its condition. The strength of the immigration is only due to the status of the stock from which those individuals have emigrated. Hence the immigrants must be regarded as an autonomous unit within the stock analyzed.

The mathematical model computes separately the population dynamics of the individuals grown up in the stock under examination and the population dynamics of its immigrated component. In this study these two components were separated based on otolith typing. Computation of the population dynamics of the individuals originating from a stock and its immigrated component was as follows:

$$
N_{2}+I_{2}=N_{1} e^{-\left(M_{N}+F_{N}+E_{N}\right)}+I_{1} e^{-\left(M_{I}+F_{I}\right)}+I^{\prime}
$$
with

$$
\begin{aligned}
N_{1} \text { and } N_{2}= & \begin{array}{l}
\text { number of individuals grown up } \\
\text { in a stock unit at time } 1 \text { and time }
\end{array} \\
& 2 .
\end{aligned} \mid \begin{aligned}
& \text { number of immigrants into a stock } \\
& \text { unit at time } 1 \text { and time } 2 .
\end{aligned}
$$




$$
\begin{aligned}
& \mathrm{M}_{1} \quad=\quad \text { natural mortality of immigrants. } \\
& \mathrm{F}_{\mathrm{I}}=\text { fishing mortality of immigrants. } \\
& \text { I' = immigration rate over the period }
\end{aligned}
$$

The above calculation is characterized by important underlying assumptions:

- The period from time 1 until time 2 must be one year.

- The migration of mature cod from East Greenland to Iceland is not taken into account (Fig. 1). This implies that the terms emigrants and immigrants refer only to the stock units off West and East Greenland and that the fish migration occurs within a closed, limited system.

- Emigrants as well as immigrants do not die during migration.

\section{The otoliths handling}

During 1984-86, left and right sagittae were collected from 13200 individual specimens caught during the groundfish surveys or by commercial trawlers. Otolith pairs were individually stored in small labelled paper-envelopes, on which the data on each fish specimen, i.e. total length, individual weight, sex and maturity, were recorded. Table 1 shows the numbers of the otolith material collected at East and West Greenland. The otolith sampling was length-stratified to ensure the collection of sagittae of at least 30 specimens per length-class (3 cm).

Only one of each pair of otoliths was aged because differences in numbers of annual zones have very rarely been recorded between the right and left sagitta (May, 1964). The otolith chosen was cut transversely across the centre using a thin, copperbladed saw running in diamond dust (Meyer, 1965). This cutting method resulted in two almost standard sections, with polished surfaces. Both sections were mounted on plasticine and examined through a binocular microscope using side illumination. In the otolith, the zones of the faster growth appear dark (opaque) while zones representing slower growth are shining bright (hyaline) when observed in transmitted light.

Age determinations were summarized to agelength keys (by year and area) assigning 1 January as the date of birth. The age-length keys were not separated by sex, because of negligible differences between sexes in growth (Hansen, 1949).

\section{Typing of annual growth zones}

Identification of nursery areas of the sampled cod was based on the typing of annual growth zones of their otoliths. Each individual annulus, consisting of one opaque and one hyaline zone, was clas- sified visually as one of three types (A, B or C). The definition of the types of annual growth zones in otoliths, as well as the standardization of typing, was developed by an international working group with the participation of scientists (3) and technical assistants (4) of the Institute for Sea Fisheries (Hamburg) and the Greenland Fisheries Research Institute (Copenhagen) and used for these standardization of typing. The annual growth zones were defined using the standard terminology for otolith readers, as established by Jensen (1963). The three different types of annual growth zones are described in Table 2.

The A-type zone (Fig. 2) is clear and shows well distinguished opaque and hyaline ring sections. The B-type (Fig. 3) has more diffused demarcations between the opaque and the hyaline areas, while the C-type zones are characterized in that the two sections can hardly be distinguished from each other. Due to their unclear and shadowy structures the annual growth zones of type C (Fig. 4) raised difficulties even to experienced otolith readers as far as the age determination was concerned.

As the mythology was prone to subjectivity, the working group held four meetings in order to standardize the typing of the annuli. Particularly, the classification of the first annulus and the separation of the B-and C-types were at the centre of extensive discussions and comparative typings. During the last exercise, a general agreement of $80 \%$ was finally achieved. Five otolith readers typed 1062 annual growth zones in 230 otoliths (Table 3 ). The working group then considered the otolith typing as reproducible and adequate.

\section{Results}

\section{Geographic distribution and cause of annulus types}

Analysis of the geographic distribution pattern of the typical annual growth zones $A, B$ and $C$ in cod otoliths gave information about their use as natural tags. Figures 5 and 6 show the occurrence of the types of annual growth zones by area. Age groups 1 to 9 for the years 1984, 1985 and 1986 were combined and the presence of the types was calculated (in per cent) for each annual growth zone.

Figure 5 demonstrates that cod off West Greenland have a clear and distinct otolith structure. The A-type was found to be dominant in each age group and each annual growth zone. The diffused B-type, laid down mainly during early life, particularly between ages 2 to 4 years, was rare. Annual growth zones of C-type were practically non existent in cod caught in West Greenland waters. 
TABLE 1. List of materials studied indicating time of otolith sampling and numbers of otoliths.

\begin{tabular}{|c|c|c|c|c|}
\hline \multirow[b]{2}{*}{ Vessel } & \multicolumn{2}{|c|}{ East Greenland } & \multicolumn{2}{|c|}{ West Greenland } \\
\hline & Date & $\begin{array}{c}\text { Number } \\
\text { of } \\
\text { Otoliths }\end{array}$ & Date & $\begin{array}{c}\text { Number } \\
\text { of } \\
\text { otoliths }\end{array}$ \\
\hline MS Wesermünde ${ }^{a}$ & 17.09.-06.10.84 & 485 & 27.09.-01.10.84 & 257 \\
\hline MS Hannovera & & & 28.09.-30.09.84 & 103 \\
\hline FS Anton Dohrn & 15.10.-23.10.84 & 384 & 25.10.-18.11.84 & 2418 \\
\hline MS Hannovera & 18.03.-27.03.85 & 648 & 28.02.-16.03.85 & 874 \\
\hline FFS Walther Herwig & 01.10.-02.11.85 & 1881 & 19.11.-11.12.85 & 2577 \\
\hline MS Hannovera & 19.03.-23.03.86 & 270 & 11.03.-11.03.86 & 199 \\
\hline MS Mainz & 30.03.-30.03.86 & 159 & & \\
\hline FFS Walther Herwig & 03.09.-02.10.86 & 1383 & 13.10.-13.11.86 & 1592 \\
\hline
\end{tabular}

a Commercial trawlers.

TABLE 2. Descriptions of the three types of annual growth zones in cod otoliths.

A-Type: The annual growth zone is divided into a compact opaque and a translucent hyaline zone. The hyaline zone consists of either a single compact ring or a few thin rings (bright in transmitted light) laying close together and clearly separated from the neighbouring opaque zones.

B-Type: The opaque and hyaline components of the annual growth zones are not compact. The diffused characteristic originates from a fine ring structure which form relatively broad transitional zones or secondary (check) rings. There is no sharp border between the zones, yet they still form an easily identifiable system of annuli.

C-Type: Some of the innermost annual growth zones are relatively easy to identify and can eventually be classified as either A- or Btype, although the hyaline component appears to be of a slightly different structure, i.e. in some cases it has a median opaque part giving the appearance of a hyaline double zone. Outside of these annuli, the otolith loses the clear separation between hyaline and opaque zones and assumes a diffused nature. Experienced readers however, might still be able to determine an age on the basis of unclear and shadowy structures.

TABLE 3. Percentage agreement between five otolith readers in the typing of 589 and 473 annual growth zones in 100 and 130 otoliths of cod caught off East and West Greenland, respectively.

\begin{tabular}{|c|c|c|c|c|c|c|c|}
\hline $\begin{array}{l}\text { Identification } \\
\text { number of the } \\
\text { otolith reader }\end{array}$ & 1 & 2 & 3 & 4 & 5 & & \\
\hline 1 & & 91 & 90 & 88 & 89 & & $\begin{array}{l}\text { W } \\
\text { e } \\
\text { s }\end{array}$ \\
\hline 2 & 81 & & 85 & 86 & 86 & 0 & $\mathrm{t}$ \\
\hline 3 & 86 & 73 & & 86 & 86 & $\begin{array}{l}\mathrm{t} \\
\mathrm{O}\end{array}$ & $\begin{array}{l}G \\
r\end{array}$ \\
\hline 4 & 86 & 78 & 83 & & 88 & i & $\begin{array}{l}\mathrm{e} \\
\mathrm{e}\end{array}$ \\
\hline 5 & $\begin{array}{r}89 \\
\text { cod } \\
\text { East }\end{array}$ & $\begin{array}{l}83 \\
\text { iths } \\
\text { hland }\end{array}$ & 87 & 84 & & $\begin{array}{l}\mathrm{t} \\
\mathrm{h} \\
\mathrm{s}\end{array}$ & $\begin{array}{l}\mathrm{n} \\
\mathrm{l} \\
\mathrm{a} \\
\mathrm{n} \\
\mathrm{d}\end{array}$ \\
\hline
\end{tabular}




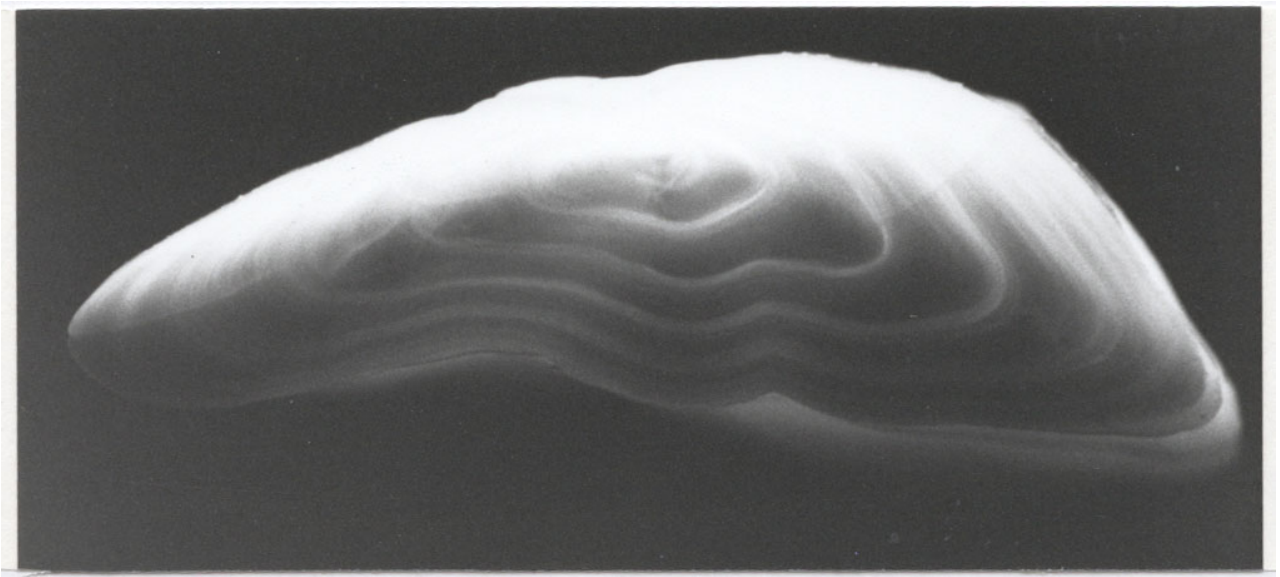

Fig. 2. Top view on the surface of a cut off cod otolith showing five annual growth zones of A-type.

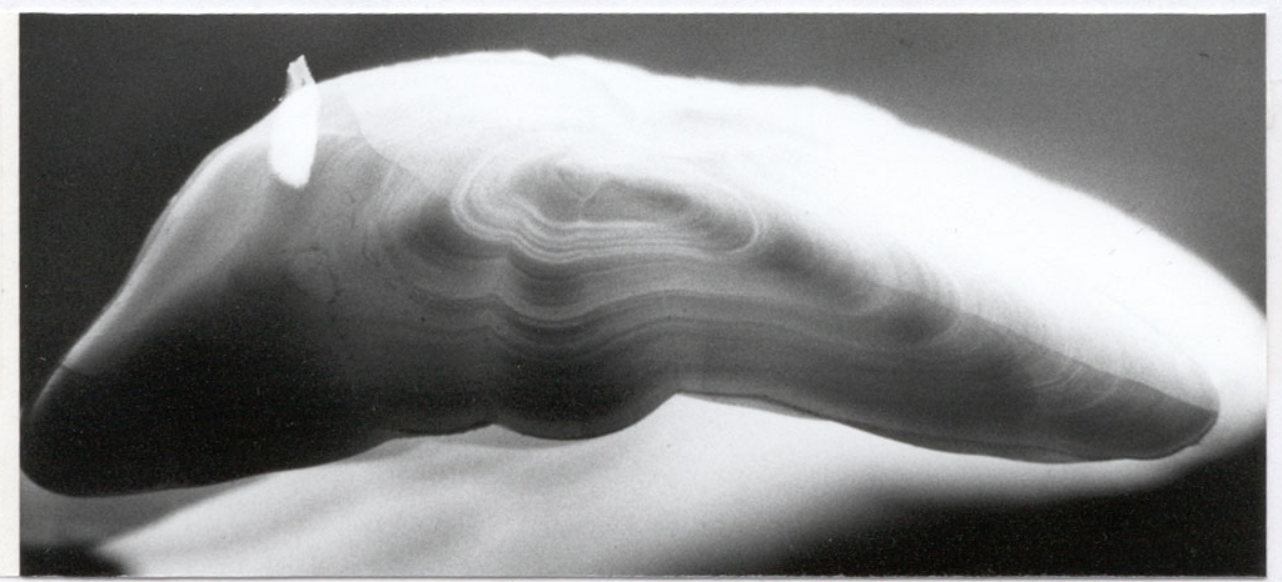

Fig. 3. Top view on the surface of a cut off cod otolith showing five annual growth zones of B-type.

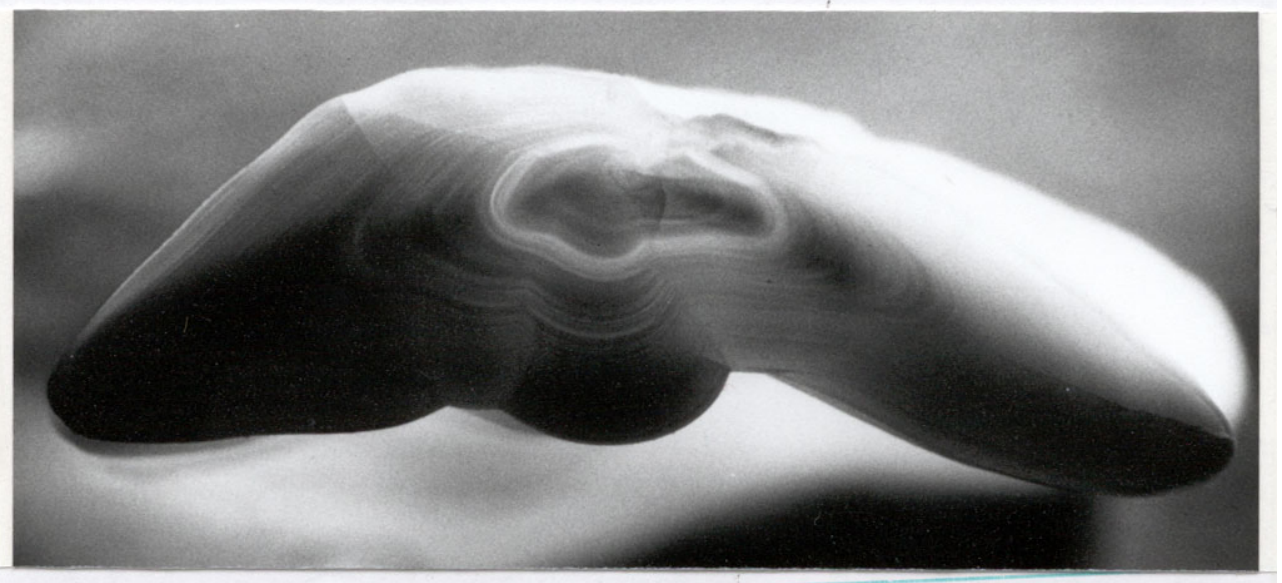

Fig. 4. Top view on the surface of a cut off cod otolith showing two annual growth zones of B-type in the central region and two annual growth zones of C-type at the edge. 


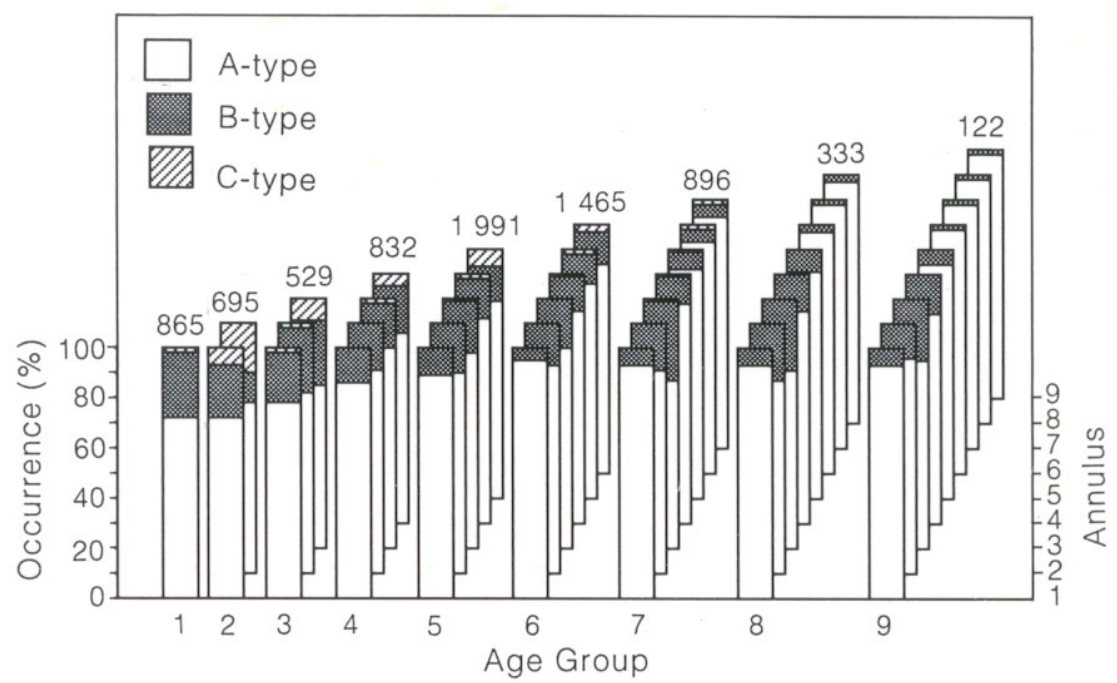

Fig. 5. Percentage occurrence of the types of annual growth zones in West Greenland cod otoliths by age group and annulus.

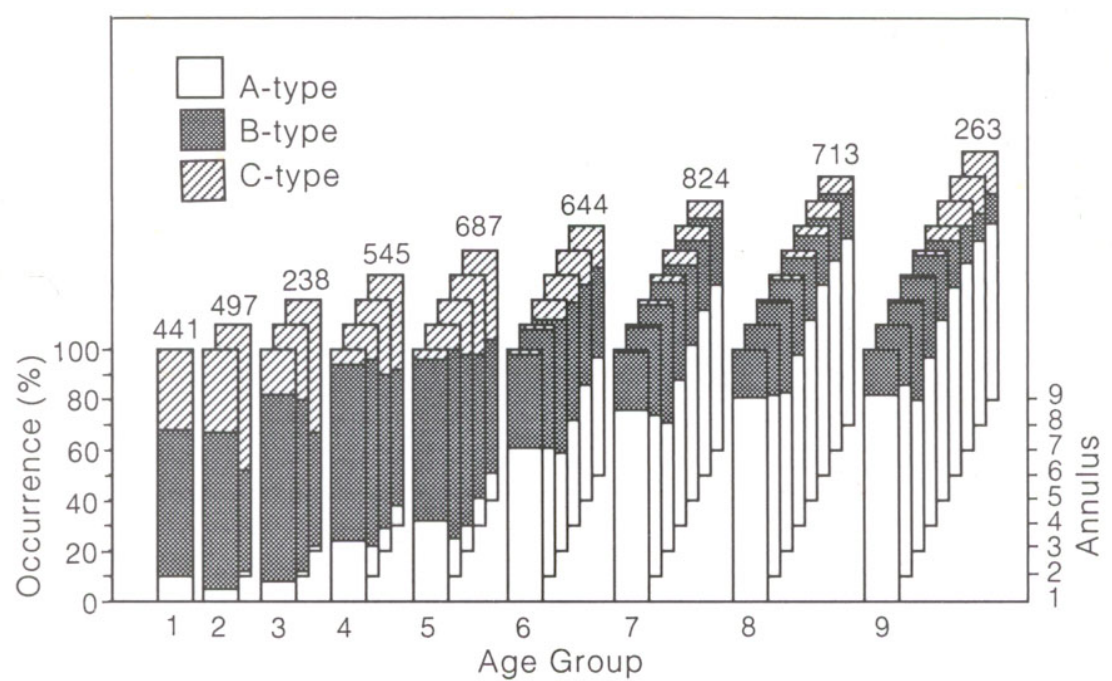

Fig. 6. Percentage occurrence of the types of annual growth zones in East Greenland cod otoliths by age group and annulus.

The types of annual growth zones off East Greenland had a different distribution pattern compared to those from West Greenland (Fig. 6). Up to the age of 5 years, the $\mathrm{B}$ - and C-types were dominant, with the A-type occurring rarely. However, the A-type gained in significance and displaced the Band $\mathrm{C}$-types in the older age groups. The C-type showed a trend to be more frequent at the edge of an otolith, as indicated in the bars in the back of Fig. 6.
Numerical classification similarities between 28 otolith samples, selected at random from the extensive material, were calculated in order to see if the information thus derived from the annual growth zones would indicate their geographic distribution pattern. The samples from West and East Greenland considered in the calculation of similarity included the otoliths of at least 30 specimens about 5 years old and younger. The numbers of $A-$, Band C-types in the otoliths of these immature 
individuals were entered into the calculation as characteristics of the otolith samples. The calculation was carried out using the coefficient called "percentage similarity" of Whittaker and Fairbanks (1958). The computations resulted in a matrix of similarity values and were classified by means of a hierarchical strategy (cluster analysis, average linkage method). A detailed description of the method for numerical classification is given in Sneath and Sokal (1973).

Similarity dendrogram classified the otolith samples into two clusters or groups (Fig. 7). The otolith samples from West Greenland fell to cluster 1, while cluster 2 consisted only of samples from East Greenland, irrespective of the year of sampling. This numerical classification demonstrated that the formation of annual growth zones was at least temporally constant for the period 1984-86.

The formation of the different annual growth zones and the growth per unit of time appeared to be correlated. Figure 8 illustrates the relation between average fish length per age group and the number of $A$-zones $(A)$ and $B$-zones (B) in the otoliths. The regressions shown in Fig. 8 are significant at the 0.05 level.

Figure 8A shows that the average length of an age group decreased with increasing numbers of A-type annual growth zones in the otoliths, while Fig. 8B shows that individuals at the age of 4 to 7 years increased in average length with increasing numbers of B-type zones. Due to the rare occurrence of C-type zones, no results could be derived from the examination. The growth analysis indicated that fast growing specimens of cod form B-type annual growth zones in their otoliths, whereas slower growing individuals form A-type zones.

\section{Algorithm for identification of nursery area}

The type of the first five annuli was taken as the criterion for identification of the nursery area, irrespective of the actual age of the specimen. Because of their absence in juvenile cod caught off East Greenland, the dominance of A-type among the first five annual growth zones was calculated. The mathematical function for computation of the dominance of A-types being:

$$
\begin{aligned}
& \mathrm{AGE}_{(\max .5)} \\
& F(x)=\Sigma A G Z(A)_{i} * 100 / A G E_{(\max .5)} \\
& i=1
\end{aligned}
$$

with

$$
\begin{array}{ll}
A G Z(A) i \quad & \begin{array}{l}
\text { annual growth zone of A-type } \\
\text { (years) } .
\end{array} \\
\text { AGE } & =\text { age of the specimen (years) } .
\end{array}
$$

If the calculated value $F(x)$ was 50 , then the number of A-type zones was the same as the number of other types of annual growth zones. If $F(x)$ was more than 50 , then the number of A-types was dominant. In this case, the central region of an otolith was clear and distinct. These cod were identified as having grown up off West Greenland. On the other hand, if the B- and C-types were dominant among the first five annual growth zones, then the value of $F(x)$ was less than 50 . Individuals distinguished by diffused central regions in their otoliths were thus identified as having grown up in East Greenland waters. Such individuals were very rare in the samples from West Greenland.

\section{Assessment}

The age disaggregated abundance indices of the cod stocks off West and East Greenland in the autumns of 1984-86 are listed in the assessment Table 4 representing the population dynamics. Only the fully recruited cohorts of 1976, 1977, 1978 and 1979 at ages 5-10 years were taken into consideration. Both stocks were divided by the above method into cod grown up within the stock unit and their immigrated components.

During the period of investigation, the 1977 and 1979 cohorts were dominant among the fully recruited year-classes. Their strengths varied from 403000 to 9120000 and from 896000 to 1752 000 individuals off West and East Greenland, respectively. The remaining cohorts of 1976 and 1978 were relatively poor in numbers and did not exceed 822000.

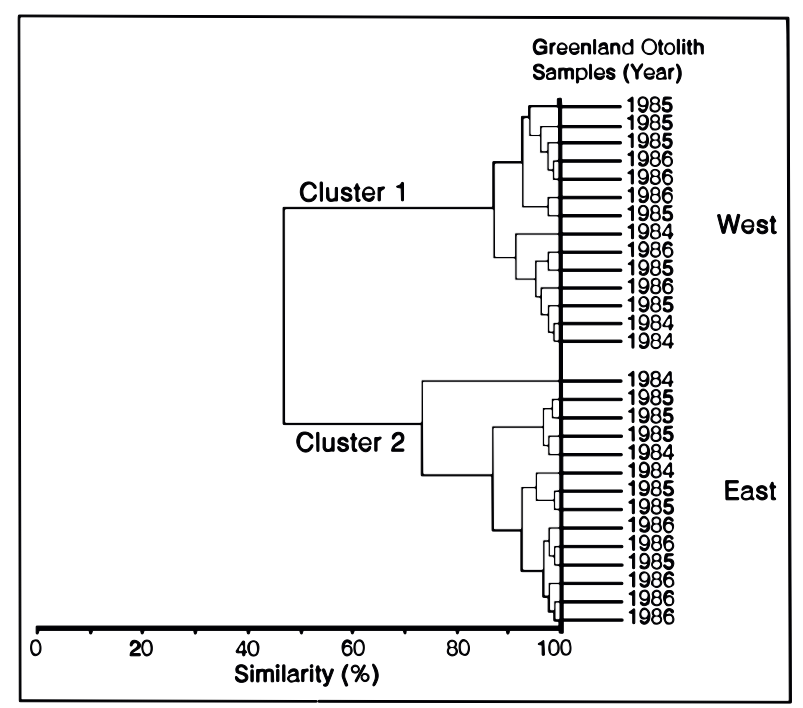

Fig. 7. Cluster analysis of otolith samples from 1984-86 (dendrogram). The similarities between the samples are illustrated (coefficient of percentage similarity, average linkage method). 

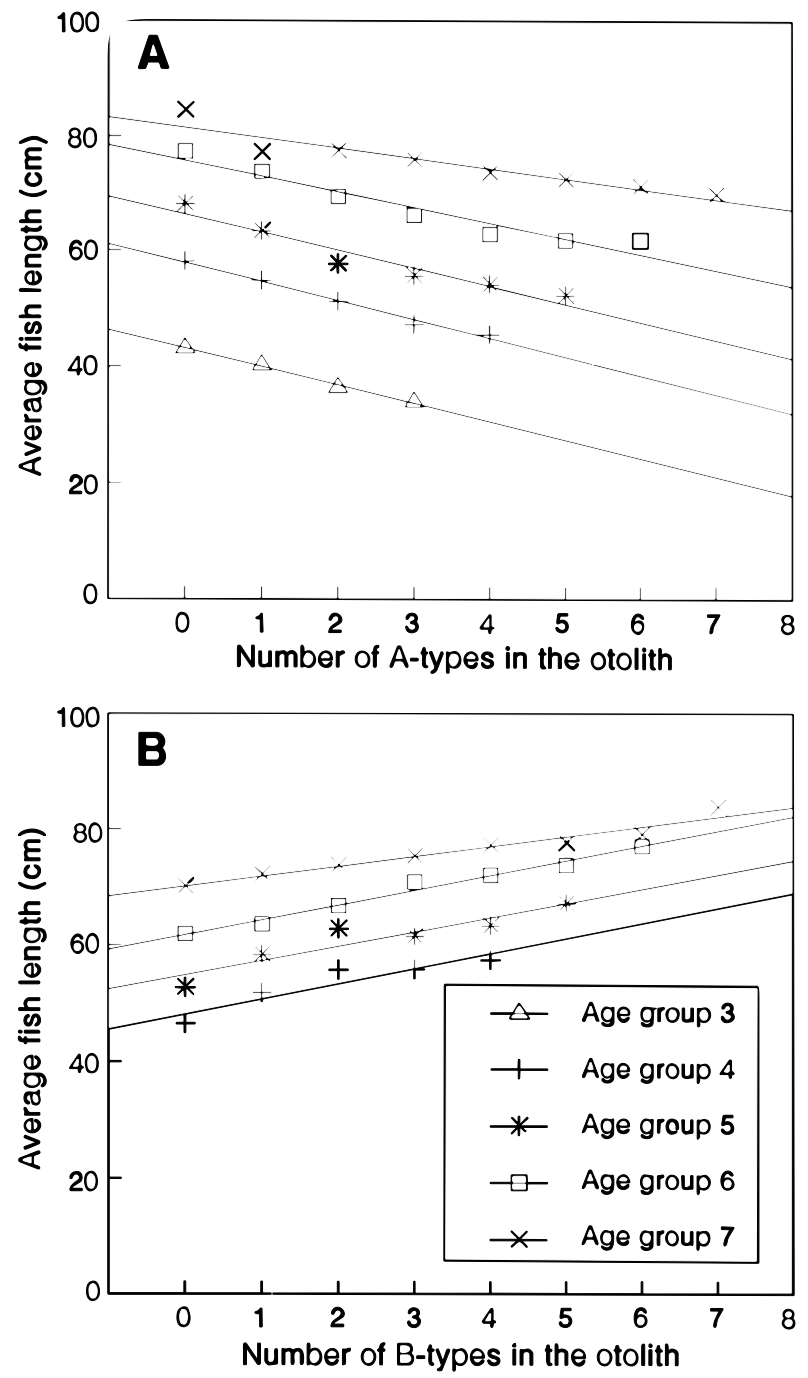

Fig. 8. Cod off Greenland. Average fish length per age group in relation to the number of $A$-zones $(\mathbf{A})$ and the number of $\mathbf{B}$-zones $(\mathbf{B})$ in the otoliths.

The values of the total mortality $Z_{\mathrm{N}+1}$ calculated separately for the cohorts of the cod stocks off West and East Greenland, and entered into the 4th column of Table 4, demonstrate the motivation for the present study. The majority of the mortality rates of the West Greenland cohorts were very high, pointing to a loss of individuals due to emigration. In contrast, the corresponding $Z_{N+1}$ values of cohorts of the East Greenland cod stock were very low (negative in some cases) and suggested an immigration.

Compared to the numbers of cod grown up within the stock off West Greenland $\left(\mathrm{N}_{\mathrm{t} 1}\right.$ and $\left.\mathrm{N}_{\mathrm{t} 2}\right)$, the numbers immigrated from East Greenland $\left(I_{t 1}\right.$ and $\mathrm{I}_{\mathrm{t} 2}$ ) were low. The instantaneous immigration rates (I') of the fully recruited cohorts were negligible or negative (negative emigration and immigration rates underline the low precision of the abundance indices!).

High rates of emigration (E') concerning the 1977 and 1979 cohorts of the cod stock off West Greenland are listed in Table 4 . From November 1984 until November 1985, the emigration of these cohorts amounted to 878000 and 558000 individuals, respectively. A year later, no positive emigration was recorded for the 1977 cohort, but the yearclass 1979 again showed a high number of emigrants (557 000). The coefficient of emigration (E) seemed to increase with age and reached a maximum of 0.85 .

During 1984-86, the dynamics of the cod stock off East Greenland were greatly influenced by immigration, as the numbers of immigrants $\left(\mathrm{I}_{\mathrm{t} 1}\right.$ and $\left.\mathrm{I}_{\mathrm{t} 2}\right)$ were very high and even exceeded the numbers of cod grown up within this area (Table $4, \mathrm{~N}_{\mathrm{t} 1}$ and $\mathrm{N}_{\mathrm{t} 2}$ ). The dominating 1977 and 1979 cohorts varied between 896000 and 1752000 individuals. Compared with the West Greenland stock, the predominance of these year-classes was less pronounced, and the remaining fully recruited cohorts 1976 and 1978 varied from 88000 to 704000 .

From October 1984 until October 1985, the numbers of instantaneous immigrated cod (I') of the 1977, 1978 and 1979 cohorts amounted to 878000 , 151000 and 558 000, respectively. During the following year, only the 1979 year-class showed a pronounced positive immigration, with 557000 individuals.

The emigration rates ( $\left.E^{\prime}\right)$ and coefficients of emigration (E) of the fully recruited cohorts of the East Greenland cod stock were very low or negative. During the period from October 1984 until October 1986, the effects of emigration were negligible.

\section{Discussion}

Biologists endeavour to use the hard tissue of fish (scales and otoliths) as information storage structures (e.g. growth, sexual development, stock identification and migration; Radtke, 1984). Majority of the descriptions of natural tags in cod otoliths available in literature can be divided into two groups. The first is distinguished from the second by subjective typing of noticeable characteristics. Rollefsen (1934) described the occurrence of narrow and broad growth zones in otoliths, and these were adopted by Godø (1984) to separate stocks. Bingel (1972) classified five types of otoliths based on the formation of the first annual growth zone only, 


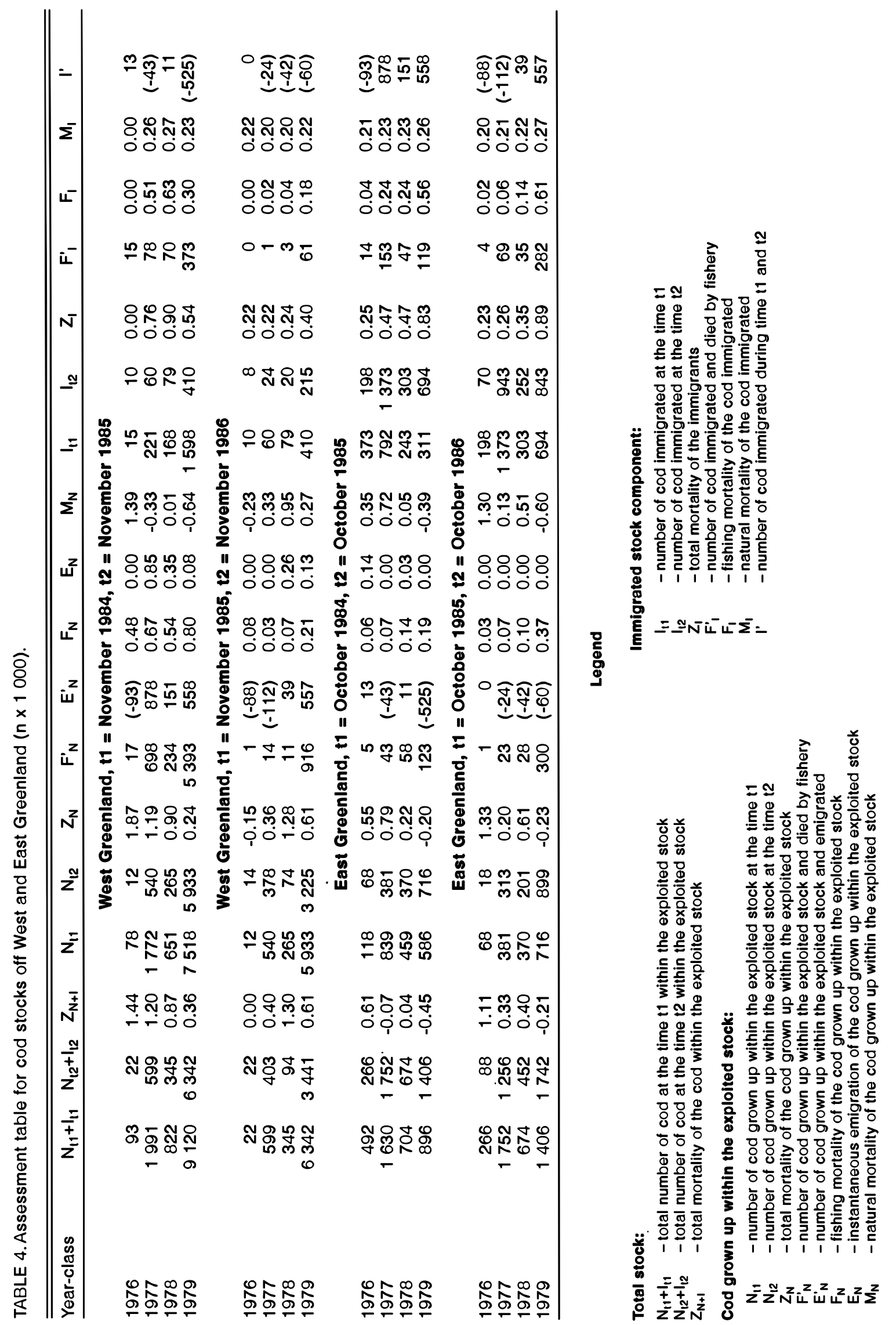


while Berner (1968) subdivided the otoliths into three types, i.e. easily determinable otoliths, difficult determinable otoliths and non-determinable ones. In contrast, the natural tag used by Trout (1954) belonged to the latter group of otolith typing, which is characterized by the measurement of the annual growth zones. Not only did he measure the dimensions of the first and second annual growth zones, like most of the other authors (L1and L2-measurements), but he also derived the pattern of growth of individuals from a measurement of all the zones. However, measurements of the annual growth increments are subject to personal valuation, particularly with regards to diffused otoliths.

In this study the individual annual growth zones were visually classified into three different types (Table 2, Fig. 2, 3 and 4). The typing, carried out in parallel to the age determination, resulted in information about the structures of the otoliths which could be analyzed quickly. The percentage agreement in the typing of annual growth zones between five readers amounted finally to $80 \%$ (Table 3 ). A further improvement in agreement in classification was not considered to be possible.

Since the different types of annual growth zones showed distinct geographic distribution patterns (Fig. 5 and 6), the identification of the nursery area of the cod, on the basis of dominance of the A-type among the first five annuli in the otolith, was possible. The appearance of the C-type at the edge of the otolith could be due to an unfavourable sampling time (the edge is normally opaque during autumn). During their first years of life, individuals were imprinted with a visually natural tag by growing up in either West or East Greenland waters. The technique described here, does not actually indicate the origin of an individual, since it provides no information as to its whereabouts prior to the formation of the first annulus. The procedure assumes that there is no difference in natural mortality which might affect significantly the occurrence of the types of annuli.

The genetic distance between sympatric cod stocks is very low (Smith et al., 1989), with only the cod stock in the Baltic which could be distinguished (Mork et al., 1985). Lühmann (1954) described the sagitta of the Baltic cod as dumpy and more compact in comparison with the elongated and more slender otoliths of the cod off Iceland. However, tagging experiments demonstrated that the cod stocks of the North Atlantic are in contact through long-distance migration of single individuals (Gulland and Williamson, 1962; Cushing, 1985). Accordingly, the appearance of the annuli is likely to vary ontogenetically. The formation of the annual growth zones appears to be influenced by the growth of the individual (Fig. 8), the growth rate itself affects translucency of the otolith, which consists mainly of calcium carbonate in the form of aragonite crystals (Dannevig, 1956; Blacker, 1969). The dominant low temperature of the West Greenland waters combined with the short seasonal warmings (Buch, 1984; Buch and Stein, 1989) probably caused the clear and distinct separation between the opaque and hyaline growth zones, which were classified as A-type. On the other hand, Stein (MS 1987) described a great instability of the meandering water masses off East Greenland. The dominant warm temperature combined with shorttime coolings probably produced faster growth and the formation of $\mathrm{B}$ - and $\mathrm{C}$-types characterized by numerous checked rings. Artemjeva and Melyantsev (1989) and Godø et al. (1987) indicated that the different otolith formation of cod belonging to the Lofoten-Barents Sea stock, the Norwegian coastal and the Northeast Arctic stock reflected differences in the environment rather than genetic variations.

The calculation model only considered the cod stocks off West and East Greenland and disregarded the fjord component of these stocks (Hovgård et al., MS 1988), as well as the emigration of adult individuals to Iceland (Fig. 1). This restriction could invalidate the results. Jones (1978) and Schopka (MS 1991) determined the emigration rate to Iceland by means of modified virtual popuIation analysis, and Easey (1978) used otolith types in order to assess the immigrated component of the Icelandic cod stock originating from Greenland. During the year of migration, the natural and fishing mortality of the migrating cod were arbitrarily determined as 0 . Non-fully recruited cohorts were rejected as they are not caught representatively by a groundfish survey. Seasonal changes of migration rates were not analyzed, as the annual groundfish survey was conducted during the autumn only. The periodic migration from banks to the fjord area was described by Jean (1964) and Templeman (1974) regarding the cod stock off Newfoundland.

The assessment confirmed the migratory behaviour of the cod off Greenland (spawning migration). This behaviour has previously been demonstrated by tagging experiments (Hansen, 1949; Horsted, 1989). During the period of investigation (1984-86), a strong emigration of West Greenland cod into the stock off East Greenland was assessed. This easterly migration amounted to 1587000 and 596000 individuals in 1984-85 and 1985-86, respectively (Table 4). The numbers of immigrants found off East Greenland contributed as much as $78 \%$ of the total strength of the older year-classes. The coefficients of emigration of the West Greenland stock seemed to increase with age. A migra- 
tion in the opposite direction, i.e. an emigration of maturing or adult individuals from the cod stock off East to West Greenland, was not indicated.

Migration of the cod off Greenland is classified as a long-distance oceanodromous migration following the definitions of McKeown (1984), which corresponds with the general concept of the migratory behaviour of fish developed by Harden Jones (1968). The migration consists of a passive larval drift along the current to the nursery grounds and an active movement of the adults back to the spawning grounds against the current. The migration of the cod off Greenland seems to be a homing phenomenon. This phenomenon designates the impulse of the movement back to the location of the own origin, which is characteristic of many fish species. The migration pattern derived from the proposed model (Table 4), however, is composed of three inseparable components, i.e. maturing cod drifted from the spawning grounds southwest off Iceland (1) and off East Greenland (2) as the 0-group and those belonging to the true West Greenland stock (3). Certainly, the variability of water temperature is one more factor having a bearing on migration, as cod off Greenland live at their northern limit. Results of transplantation experiments of Baltic cod support a strong direct link between migration and hydrographic conditions (Otterlind, 1985). A positive rheotaxis might be the mechanism of orientation.

\section{Acknowledgements}

This study was supported by the Bundesministerium für Forschung und Technologie, FRG. D. Sahrhage supported the study at the Institute for Sea Fisheries (Hamburg) in every possible way. I am indebted to A. Schumacher for scientific deliberation and to K. Lillelund and to D. Bürkel for critical comments on the text. Sv. Aa. Horsted, M. Georges, I. Meldal, R. Grimm and R. Larsen participated in the working group on otolith typing. I also thank S. Ehrich, F. Köster and P. Cornus for their helpful discussions. M. Marten assisted in the computer programming.

\section{References}

ANON. 1973. Report of the ICES/ICNAF working group on cod stocks in the North Atlantic. ICES Coop. Res. Rep., 33-43: 1-52.

1990. Reports of Scientific Council. NAFO Sci. Coun. Rep., 1990, p. 45-52.

MS 1990. Report of the working group on cod stocks off East Greenland. ICES C.M. Doc., No. A:12, $51 \mathrm{p}$.

ARTEMJEVA, K. F., and R. V. MELYANTSEV. 1989. Evaluation of heterogeneity of the Lofoten-Barents Sea cod stock. ICES C.M. Doc., No. G:11, 9 p.

BERNER, M. 1968. Einige orientiernde untersuchungen an den otolithen des dorsches (Gadus morhua L.) aus verschiedenen regionen. (Investigations of cod otoliths originating from different areas). FischereiForschung, (6): 77-86.

BINGEL, F.1972. Zur interpretation von otolithenstrukturen des dorsches (Gadus morhua L.). (Interpretation of structures in cod otoliths). Dipl. Arb. Math.-Nat. Fak., University Kiel.

BLACKER, R. W. 1969. Chemical composition of the zones in cod (Gadus morhua) otoliths. ICES J. Cons., 33(1): 107-108.

BUCH, E. 1984. Variations in the temperature and salinity of West Greenland waters, 1970-82. NAFO Sci. Coun. Studies, 7: 39-43.

BUCH, E., and M. STEIN. 1989. Environmental conditions off West Greenland, 1980-85. J. Northw. Atl. Fish. Sci., 9: 81-89.

COCHRAN, W. G. 1977. Sampling techniques. John Wiley and Sons Inc., New York, 3. Ed.

CUSHING, D. H. 1985. Emigration of fish: a change in opinion. La mer, 2:1-5.

DANNEVIG, E. H. 1956. Chemical composition of zones of cod otoliths. ICES J. Cons., 21: 156-159.

EASEY, M. W. 1978. Otolith typing as an aid in the assessment of the contribution of Greenland cod to the fishery at Iceland. ICES C.M. Doc., No. G:31, 9 p.

GOD $\varnothing$, O. R. 1984. Cod (Gadus morhua) off more-composition and migration. Flodevigen rapportser. 1, The Propagation of Cod (Gadus morhua L.), E. Dahl, D. S. Danielssen, E. Moksness and P. Solemdal (ed.), p. 591-608.

GODØ, O. R., E. MOKSNESS, D. R. GUNDERSON, and S. SUNDBY. 1987. Growth and maturation of Norwegian coastal cod and northeast Arctic cod under different conditions. Fish. Res., 5 (2-3): 235-242.

GULLAND, J. A., and G. R. WILLIAMSON. 1962. Transatlantic journey of cod. Nature, 1915: 191.

HANSEN, P. M. 1949. Studies on the biology of cod in Greenland waters. ICES Rapp. Proc.-Verb., 123: 177.

HARDEN JONES, F. R. 1968. Fish Migration. Edw. Arnold Ltd., London, $325 \mathrm{p}$.

HORSTED, Sv. Aa. 1989. Some features of oceanographic and biological conditions in Greenland waters. Proceedings of the Sixth Conference of the Comite Arctique International 13-15 May 1985, L. Rey and V. Alexander, E. J. Brill (ed.) (New York), p. 456-476.

HOVGÅRD, H., K. H. NYGARD, and K. M. LEHMANN. MS 1988. Inshore and offshore distribution and abundance of the West Greenland cod stock, autumn 1987. NAFO SCR Doc., No. 43, Serial No. N1483, $13 \mathrm{p}$.

IHSSEN, P. E., H. E. BOOKE, J. M. CASSELMAN, J. M. MCGLADE, N. R. PAYNE, and F. M. UTTER. 1981. Stock identification: materials and methods. Can. J. Fish. Aquat. Sci., 38: 1838-1855.

JEAN, Y. 1964. Seasonal distribution of cod (Gadus morhua L.) along the Canadian Atlantic coast in relation to water temperature. J. Fish. Res. Board. Can., 21(1): 429-460.

JENSEN, A. C. 1963. A standard terminology and notation for otolith age readers. ICNAF Redbook(II): 131134.

JONES, B. W. 1978. The potential contribution of cod from Greenland to the fishery at Iceland. ICES C.M. Doc., No. G:17, 15 p. 
LÜHMANN, M. 1954. Die wachstumsveränderungen der körperproportionen und einzelner körperteile und organe beim ostseedorsch. (Changes in growth and morphometric proportions of Baltic cod). Ber. Dtsch. Wiss. Komm. Meeresforsch., 13(4): 327-346.

MAGNÚSSON, J., S. SVEINBJÖRNSSON, and V. HELGASON. 1989. Report on O-group fish survey in Iceland and East Greenland waters, Aug.-Sep. 1989. ICES C.M. Doc., No. G:52, 17 p.

MAY, A. W. 1964. An asymmetrical pair of cod otoliths. J. Fish. Res. Board. Can., 21(1): 413-415.

MCKEOWN, B. A. 1984. Fish migration. Timber Press, Portland Oregon, $224 \mathrm{p}$.

MEYER, A. 1965. Sawing otoliths as mechanical aid of otolith reading. ICNAF Res. Bull., 2: 78-79.

MORK, J., N. RYMAN, G. STAHL, F. UTTER, and G. SUDNES. 1985. Genetic variation in Atlantic cod (Gadus morhua) throughout its range. Can. J. Fish. Aquat. Sci., 42: 1580-1587.

OTTERLIND, G. 1985. Cod migration and transplantation experiments in the Baltic. J. Appl. Ichthyol., (1): 316.

RADTKE, R. L. 1984. Cod fish otoliths. Information storage structures. Flodevigen rapportser. 1, The Propagation of cod (Gadus morhua L.), E. Dahl, D. S. Danielssen, E. Moksness and P. Solemdal (ed.), p. 273-298.

RICKER, W. E. 1975. Computation and interpretation of biological statistics of fish populations. Bull. Fish. Res. Board. Can., 191, 382 p.

ROLLEFSEN, G. 1934. The cod otolith as a guide to race, sexual development and mortality. ICES Rapp. Proc.Verb., 88(2): 1-15.

SAVILLE, A. 1977. Survey methods of appraising fishery resources. FAO Fish. Tech. Pap., 171: 1-76

SCHMIDT, J. 1931. Summary of the Danish marking experiments on cod 1904-1929, at the Faroes, Iceland and Greenland. ICES Rapp. Proc.-Verb., 72(3): 313.

SCHOPKA, S. A. MS 1991. The Greenland cod at Iceland 1941-1990 and its impact on assessment. NAFO SCR Doc., No. 102, Serial No. N1994, 7 p.

SMITH, P. J., A. BIRLEY, A. JAMIESON, and C. A. BISHOP. 1989. Mitochondrial DNA in the Atlantic cod, Gadus morhua: lack of genetic divergence between eastern and western populations. J. Fish Biol., 34: 369-373.

SNEATH, P. H. A., and R. R. SOKAL. 1973. Numerical taxonomy. The principles and practice of numerical classification. San Francisco (Freeman \& Co.), $573 \mathrm{p}$.

STEIN, M. MS 1987. On the variability of water masses, currents and ice in Denmark Strait. NAFO SCR Doc., No. 6, Serial No. N1274, $21 \mathrm{p}$.

TEMPLEMAN, W. 1974. Migrations and intermingling of Atlantic cod (Gadus morhua) stocks of the Newfoundland area. J. Fish. Res. Board. Can., 31(6): 10731092.

TROUT, G. C. 1954. Otolith growth of the Barents Sea cod. ICES Rapp. Proc.-Verb., 136: 89-102.

WHITTAKER, R. H., and C. W. FAIRBANKS. 1958. A study of plankton copepod communities in the Columbia Basin, southeastern Washington. Ecology, 39(1): 46-65. 